\title{
Co-expression of nuclear and cytoplasmic HMGB1 is inversely associated with infiltration of CD45RO+ $T$ cells and prognosis in patients with stage IIIB colon cancer
}

\author{
Rui-Qing Peng ${ }^{1,2}$, Xiao-Jun Wu $\mathrm{W}^{1,3}, \mathrm{Ya} \mathrm{Ding}^{1,2}$, Chun-Yan Li, $\mathrm{i}^{1,5}$, Xing-Juan $\mathrm{Yu}^{1,4}$, Xing Zhang ${ }^{1,2}$, Zhi-Zhong Pan ${ }^{1,3}$, \\ De-Sen Wan ${ }^{1,3}$, Li-Ming Zheng ${ }^{1,2}$, Yi-Xin Zeng ${ }^{1,2,4}$, Xiao-Shi Zhang ${ }^{1,2^{*}}$
}

\begin{abstract}
Background: The intratumoral infiltration of T cells, especially memory $T$ cells, is associated with a favorable prognosis in early colorectal cancers. However, the mechanism underlying this process remains elusive. This study examined whether high-mobility group box 1 (HMGB1), a damage-associated molecular pattern (DAMP) molecule, is involved in the infiltration of T cells and disease progression in locally advanced colon cancer.

Methods: Seventy-two cases of pathologically-confirmed specimens were obtained from patients with stage IIIB (T3N1M0) colon cancer who underwent radical resection between January 1999 and May 2002 at the Cancer Center of Sun Yat-Sen University. The density of tumor-infiltrating lymphocytes (TILs) within the tumor tissue and the expression of HMGB1 in the cancer cells were examined via immunohistochemical analysis. The phenotype of CD45RO+ cells was confirmed using a flow cytometric assay. The association between HMGB1 expression, the density of TILs, and the 5-year survival rate were analyzed.

Results: The density of CD45RO+ T cells within the tumor was independently prognostic, although a higher density of CD3 + T cells was also associated with a favorable prognosis. More importantly, the expression of HMGB1 was observed in both the nucleus and the cytoplasm (co-expression pattern) in a subset of colon cancer tissues, whereas nuclear-only expression of HMGB1 (nuclear expression pattern) existed in most of the cancer tissues and normal mucosa. The co-expression pattern of HMGB1 in colon cancer cells was inversely associated with the infiltration of both $\mathrm{CD} 3+$ and $\mathrm{CD} 45 \mathrm{RO}+\mathrm{T}$ cells and 5-year survival rates.

Conclusions: This study revealed that the co-expression of HMGB1 is inversely associated with the infiltration of $\mathrm{CD} 45 \mathrm{RO}+\mathrm{T}$ cells and prognosis in patients with stage IIIB colon cancer, indicating that the distribution patterns of HMGB1 might contribute to the progression of colon cancer via modulation of the local immune response.
\end{abstract}

\section{Background}

Colorectal cancer is one of the most common causes of cancer deaths worldwide [1]. The median overall survival of patients with metastatic colorectal cancer has increased from 12 months to approximately 24 months over the past decade as a result of improvements in systemic therapies, including new chemotherapeutic agents

\footnotetext{
* Correspondence: zxs617@hotmail.com

'State Key Laboratory of Oncology in South China, 651 Dongfeng R E, 510060, Guangzhou, China

Full list of author information is available at the end of the article
}

such as irinotecan and oxaliplatin and monoclonal antibodies against epidermal growth factor receptor (EGFR) and vascular endothelial growth factor (VEGF). However, the 5-year survival of patients is still poor [2-5]. Thus, one of the main challenges for the treatment of colorectal cancer remains to identify new strategies beyond chemotherapy to inhibit disease progression.

Colorectal cancers are characterized by infiltration with multiple stromal cells, among which are tumorinfiltrating lymphocytes (TILs) that act as prognostic and predictive factors [6-15]. TILs include natural killer

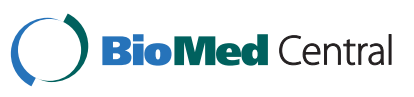


(NK) cells, CD8+ T cells, and CD4+ T cells, including Th1, Th2, Th17, and Treg cells. Although the role of TILs in tumor progression is controversial, CD45RO+ $\mathrm{T}$ cells have been identified as the main anti-tumoral effectors in early colorectal cancers. Hierarchical clustering has shown that markers of T-cell migration, activation, and differentiation are increased in tumors without signs of early metastatic invasion. These tumors have an increased number of $\mathrm{CD} 8+\mathrm{T}$ cells, ranging from early memory (CD45RO+, CCR7-, CD28+, and CD27+) to effector memory (CD45RO+, CCR7-, CD28-, and CD27-) T cells. The presence of high levels of infiltrating memory $\mathrm{CD} 45 \mathrm{RO}+\mathrm{T}$ cells is correlated with the absence of signs of early metastatic invasion, a less advanced pathologic stage, and increased survival, which has been confirmed in several series of patients $[16,17]$. These correlations indicates that protective immune responses exist in a subset of colorectal cancer patients. Activated tissue-resident memory $\mathrm{T}$ cells, which have a potent lytic potential with the expression of perforin and granzyme B, are not only capable of providing immediate effector function at the site of cancer cells but can also generate an effective secondary immune response [18-21]. Radiotherapy and some chemotherapeutics have the potential to induce the immunogenic death of cancer cells and subsequently activate memory $\mathrm{T}$ cells. Furthermore, clinical trials have shown that the efficacy of chemotherapy against colon cancer can be improved when combined with cytokines [22-27]. These data indicate that the activation of memory $\mathrm{T}$ cells that have infiltrated into tumor tissues might be a promising therapeutic strategy.

Tissue-resident memory $\mathrm{T}$ cells result from the acute immune response, which may be induced by damageassociated molecular pattern molecules (DAMPs). Highmobility group box 1 (HMGB1), previously named HMG1, amphoterin, and sulfoglucuronyl carbohydrate binding proteinis a DAMP. Under physiologic conditions, HMGB1 localizes in the nucleus. HMGB1 is released into the extracellular matrix by spontaneous release or by dying cells. HMGB1 is a multi-functional protein that accelerates cell growth, invasion, and angiogenesis in cancer tissues, induces apoptosis in macrophages, and promotes immune responses [28-31]. With respect to modulation of the immune response, HMGB1 binds to surface receptors expressed on dendritic cells (DCs), leading to the maturation of DCs, antigen processing, and a subsequent protective effect. There is also evidence that HMGB1 induces immune tolerance by interfering with the antigen-presenting process and decreasing the number of DCs or by binding to the TLR9 agonist, which leads to human plasmacytoid DC suppression [32-36]. In addition, extracellular HMGB1 triggers the inflammatory cascade through multiple pathways, facilitating progression of the tumor.

Because HMGB1 has a dual effect on tumor progression, the feasibility of targeting the release of HMGB1 remains elusive. To this end, this study determined whether the expression of HMGB1 is related to the infiltration of $\mathrm{T}$ cells and patient prognosis in locally advanced colon cancers.

\section{Methods \\ Materials}

Seventy-two cases of pathologically-confirmed specimens matched with adjacent normal mucosa were obtained from patients with stage IIIB (T3N1M0; AJCC, 2002) colon cancer between January 1999 and May 2002 at the Cancer Center of Sun Yat-Sen University in Guangzhou, China (Table 1). All of the patients underwent radical resection and 5-FU-based adjuvant chemotherapy postoperatively for 6 months. Patients were evaluated every 3 months during the $1^{\text {st }}$ year, every 6 months in the $2^{\text {nd }}$ year, and by telephone or mail communication once every year thereafter for a total of 5 years. If recurrence or metastasis occurred, 5-FU-based chemotherapy was given according to the NCCN guidelines. Overall survival was defined as the time from surgery to death. Alternatively, censoring was done at the last known date the patient was alive. This study was approved by the institutional ethical review committee of Sun Yat-Sen University Cancer Center.

\section{Immunohistochemical assay and scoring systems}

Formalin-fixed, paraffin-embedded archived tissues were cut into $4-\mu \mathrm{m}$ sections. The size of each tissue section

Table 1 Patient Characteristics $(\mathrm{N}=\mathbf{7 2}$ )

\begin{tabular}{ll}
\hline Characteristic & No. of patients (\%) \\
\hline Age, years & $33(45.8)$ \\
$<60$ & $39(54.2)$ \\
$\geq 60$ & \\
Gender & $40(55.6)$ \\
Male & $32(44.4)$ \\
Female & \\
Tumor sites & $46(63.9)$ \\
Left hemicolon & $26(36.1)$ \\
Right hemicolon & \\
Pathological grade & $10(13.9)$ \\
G1 & $54(75.0)$ \\
G2 & $8(11.1)$ \\
G3 & \\
Survival time, months & $52(72.2)$ \\
$\geq 60$ & $20(27.8)$ \\
\hline 60 &
\end{tabular}


was about $1.0 \mathrm{~cm} \times 1.5 \mathrm{~cm}$. Then, the sections were de-waxed, rehydrated, blocked with hydrogen peroxide, and the antigens were retrieved in a microwave in $10 \mathrm{mM}$ citrate buffer ( $\mathrm{pH}$ 6.0) for 10 minutes and cooled to room temperature. After blocking with sheep serum, the sections were incubated overnight at $4^{\circ} \mathrm{C}$ with either rabbit polyclonal antibody against human HMGB1 at a dilution of 1:1000 (Abcam, Cambridge, MA, USA) or mouse monoclonal antibody against human CD3, CD45RO, CD4, CD8, and CD56. All of these antibodies (Zymed, San Diego, CA, USA) were diluted 1:100. Subsequently, biotinylated secondary antibodies and streptavidin-biotinylated horseradish peroxidase complex were used. The sections were developed with diaminobenzidine tetrahydrochloride (DAB) and counterstained with hematoxylin. Negative controls were employed in which the primary antibody was replaced by phosphate-buffered solution (PBS).

The density of TILs within the tumors and the expression of HMGB1 in cancer cells were scored with two scoring systems. Hussein's method was used to score the density of TILs as follows: 1) the cells were counted in at least 10 different fields of each section, and the size of each high-power field $(\times 400)$ was about 300 $\mu \mathrm{m} \times 300 \mu \mathrm{m} ; 2)$ the cells were counted in the tumor stroma; 3 ) the areas of highest density were chosen; 4) necrotic areas were avoided; 5) two observers counted the cells at the same time and in the same field using a multiple-lens microscope; and 6) the results were expressed as the mean \pm standard error of the mean [37]. The expression of HMGB1 was interpreted via immunoreactivity using the 0-4 semi-quantitative system derived from Soumaoro [38] for both the intensity of staining and the percentage of positive cells (labeling frequency percentage). The intensity of nuclear or cytoplasmic staining was grouped into the following four categories: no staining/background of negative controls (score $=0$ ), weak staining detectable above background (score $=1)$, moderate staining (score $=2$ ), and intense staining (score $=3$ ). The labeling frequency was scored as $0(\leq 1 \%), 1(1 \%-24 \%), 2(25 \%-49 \%), 3(50 \%-74 \%)$, and $4(\geq 75 \%)$. The sum index was obtained by totaling the intensity and percentage scores, as follows: $(-),(+),(++)$, and $(+++)$ indicated sum-indexes of $0-1,2-3,4-5$, and 6-7, respectively; $(-)$ and $(+)$ were defined as no or modest expression, and $(++)$ and $(+++)$ were defined as strong expression. Each section was independently scored by two pathologists. If an inconsistency occurred, a third pathologist was consulted to achieve consensus.

\section{Double immunohistochemistry for HMGB1 and CD45RO}

Double immunohistochemical staining was performed with a Polymer kit (GBI, Seattle, WA, USA). The sections were simultaneously incubated with two primary antibodies derived from different species. After blocking nonspecific binding with goat serum, the sections were incubated overnight at $4^{\circ} \mathrm{C}$ with a rabbit anti-human HMGB1 polyclonal antibody (1:1000; Abcam, Cambridge, MA, USA) and a mouse anti-human CD45RO monoclonal antibody (1:100; Zymed, San Diego, CA, USA) simultaneously. After washing in PBS, the sections were incubated with both alkaline phosphatase-labeled goat anti-rabbit IgG antibodies and horse radish peroxidase-labeled goat anti-mouse IgG antibodies with a definite percentage for 30 minutes at room temperature. After three washes with PBS, sections were developed sequentially with DAB and AP-Red and counterstained with hematoxylin. Negative controls were employed in which both of the primary antibodies were replaced with PBS.

\section{Flow-cytometric analysis}

Fresh tumor specimens were processed via sterile mechanical dissection. The tissue was cut into small pieces and stirred for 2 hours at $37^{\circ} \mathrm{C}$ in an enzymatic bath containing RPMI 1640 (Invitrogen, San Diego, CA, USA) and HEPES buffer $(20 \mathrm{mmol} / \mathrm{L})$ containing penicillin/streptomycin $(120 \mu \mathrm{g} / \mathrm{ml}$ and $100 \mathrm{ug} / \mathrm{ml}$, respectively), fungizone $(0.25 \mathrm{mg} / \mathrm{ml})$, ceftazidime $(50 \mu \mathrm{g} / \mathrm{ml})$, collagenase type III $(200 \mathrm{U} / \mathrm{ml})$, and DNase type $\mathrm{I}(100 \mathrm{U} / \mathrm{ml})$. The suspension was then filtered through two wire grids (70 and $40 \mu \mathrm{m}$ ), and the cells were washed three times with Hank's balanced salt solution (HBSS). Subsequently, cells were separated on a Percoll density gradient (Pharmacia Biotech AB, Uppsala, Sweden) for $30 \mathrm{~min}$ at $1500 \times g$ at room temperature. The dense layer, enriched for lymphocytes, was collected and washed. Then the cells were incubated for 30 minutes at $4{ }^{\circ} \mathrm{C}$ with antibodies conjugated to APC against CD3 (Biolegend, San Diego, CA, USA) and phycoerythrin (PE) against CD45RO (Biolegend, San Diego, CA, USA). Analyses were performed with a five-color fluorescence-activated cell sorter (FC500; Beckman-Coulter, Fullerton, CA, USA) and Cxp cytometer software (Beckman-Coulter, Fullerton, CA, USA). Immune subpopulations were measured as a percentage of the total number of all cells and a percentage of the total number of $\mathrm{CD} 3+$ cells.

\section{Statistical analysis}

The correlation between the density of TILs or HMGB1 expression with patient characteristics and the correlation between the density of TILs and levels or subcellular location of HMGB1 were analyzed with a chi-square test or Fisher's exact test. The following factors were assessed with both univariate and multivariate analyses to determine their influence on overall survival: gender, age, pathologic grade, tumor site, the density of CD3+ cells, 
the density of CD45RO+ cells, and the level or subcellular location of HMGB1 expression within colon cancer tissues. Kaplan-Meier curves were used to estimate the distributions of those variables in relation to survival, which were compared using the log-rank test. The Cox regression model was used to correlate assigned variables with overall survival. All statistical analyses were carried out using SPSS 13.0 software (SPSS Inc., Chicago, IL, USA). Statistical significance was assumed for a twotailed $P<0.05$.

\section{Results}

Patterns of TIL infiltration and HMGB1 expression within stage IIIB colon cancer tissues

CD3+ and CD45RO+ cells were observed in all cases in the tumor stroma and the adjacent normal mucosa different extents. Both antigens stained the cell membrane.
In addition, we performed immunostaining against CD4, CD8, and CD56 in 10 of the tissue sections to determine which of these proteins might play an important role in this group of patients. Among the CD3+ cells, CD8+ cells outnumbered CD4+ cells, while CD56+ cells were rare (Fig. 1, 2. To confirm the phenotype of the CD45RO + cells, co-expression of CD3 with CD45RO was examined in five fresh cancer tissues via flow cytometry, which indicated that $72 \%$ of all tumor-infiltrating CD45RO+ lymphocytes were also CD3-positive (Fig. 3).

Although HMGB1 staining existed only in the nucleus in normal mucosa, co-expression of nuclear and cytoplasmic HMGB1 (co-expression pattern) existed in a subset of cancer tissues (12/65 [18.5\%]), whereas most of the cancer tissues only showed nuclear staining of HMGB1 (nuclear expression pattern; 53/65 [81.5\%]; Table 2, Fig. 4).

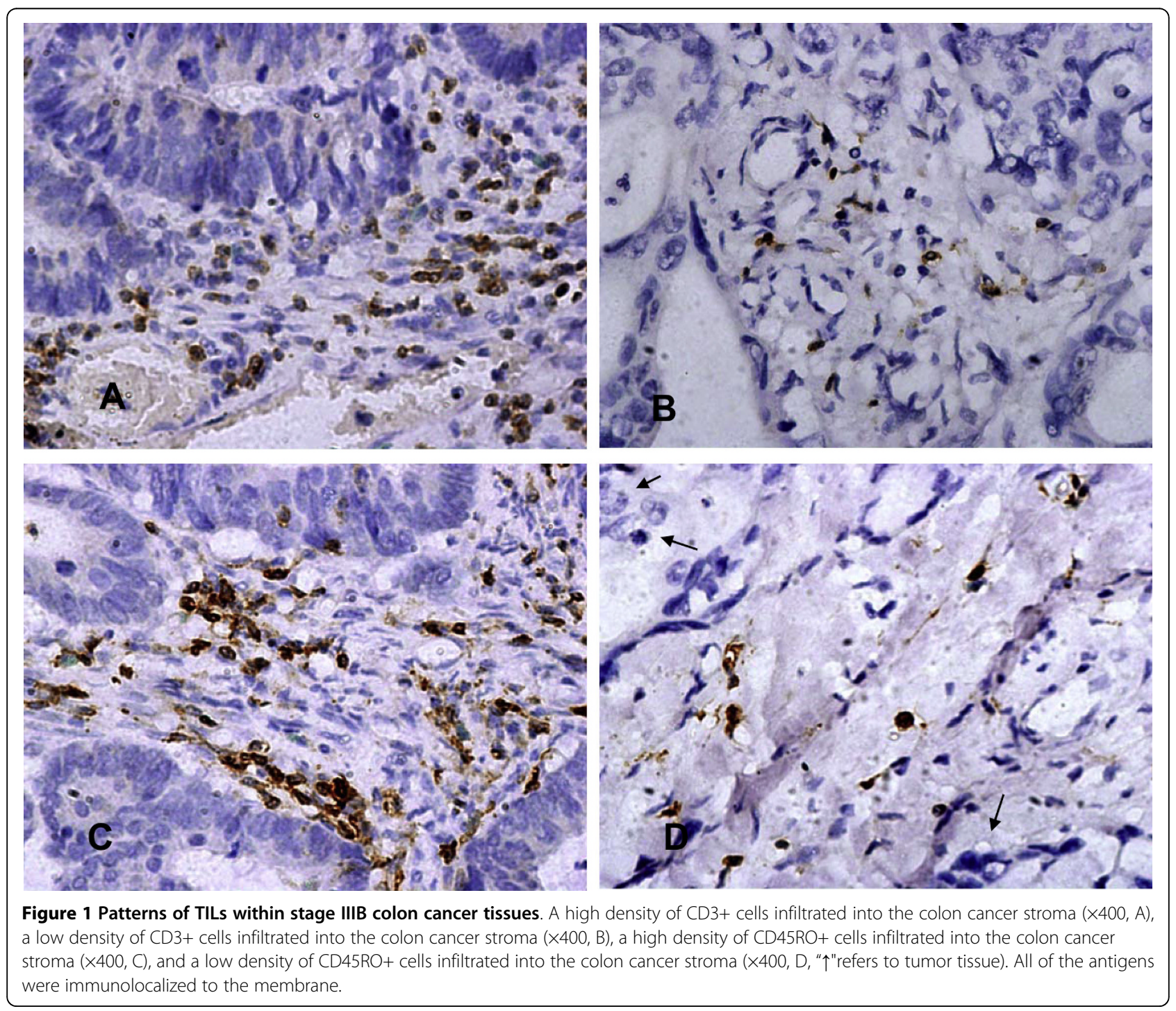



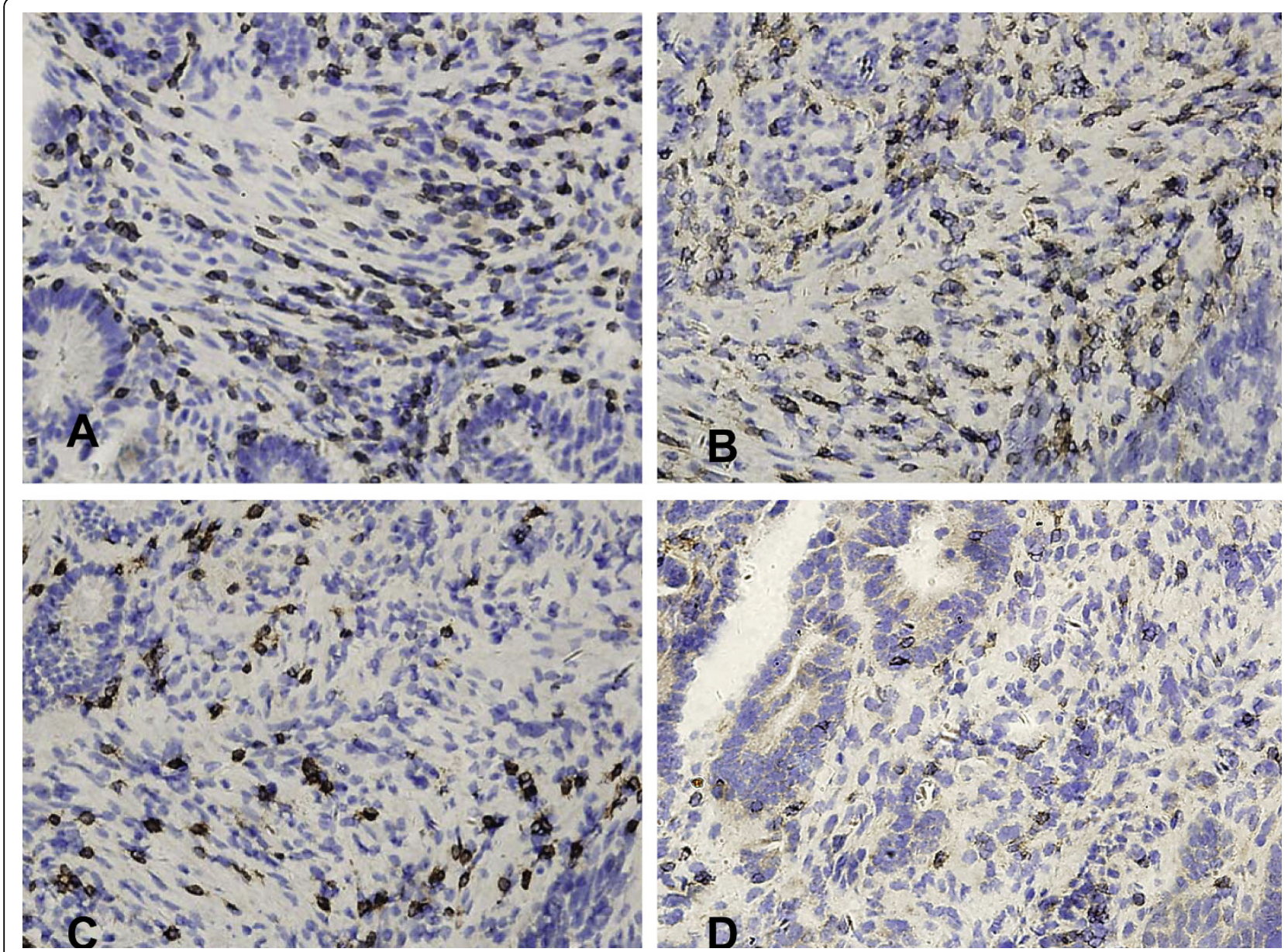

Figure 2 Subtype of CD3+ cells within stage IIIB colon cancer tissues. A high density of CD3+ cells infiltrated into the colon cancer stroma $(\times 400, A)$; CD4+ cells infiltrated into the colon cancer stroma $(\times 400, B), C D 8+$ cells infiltrated into the colon cancer stroma $(\times 400, C)$, and CD56+ cells infiltrated into the colon cancer stroma $(\times 400, D)$. All of the antigens were immunolocalized to the membrane.

The relationship between HMGB1 expression and the density of CD3+ or CD45RO+ cells

The density of TILs within the tumors was within the $75^{\text {th }}$ percentile for all those specimens in which the survival difference between the "high" and "low" groups was the largest [17]. The cut-off values for the density of CD3+ and CD45RO+ cells were 16 and 24 cells per high-power field in the center of the tumor, respectively. Thus, the density of CD3+ cells was recorded as high if $>16$ cells were observed per high-power field, and the same cutoff used for CD45RO+ cells. The log-rank test was used to compare the level of HMGB1 with the density of CD3+ and CD45RO+ cells within the tumor. A stronger expression $(++-+++)$ of HMGB1 was associated with a higher density of both CD3+ and CD45RO + cells (Table 3, Fig. 5). Furthermore, the log-rank test was used to compare the subcellular localization of HMGB1 with the density of CD3+ and CD45RO+ cells within the tumor. The co-expression pattern of HMGB1 in the nucleus and cytoplasm was inversely associated with infiltration of both CD3+ and CD45RO+ cells, respectively (Table 4, Fig. 5).

Relationship between the density of TILs, HMGB1, clinical characteristics, and 5-year survival rate as analyzed via univariate analysis

The log-rank test was used to compare the density of CD3+ cells and CD45RO+ cells and the level of HMGB1 with patient characteristics. The density of CD3+ cells within the tumor stroma was associated with pathologic grades $(P=0.023)$, i.e., a lower pathologic grade was associated with less $\mathrm{CD} 3+$ cell infiltration. However, neither the density of the CD45RO+ cells nor the levels of HMGB1 were associated with any of the clinical characteristics.

By the end of the 5-year follow-up period, 52 patients were alive, making the 5 -year survival rate equal to $72 \%$ in this group of patients. Kaplan-Meier survival analysis 


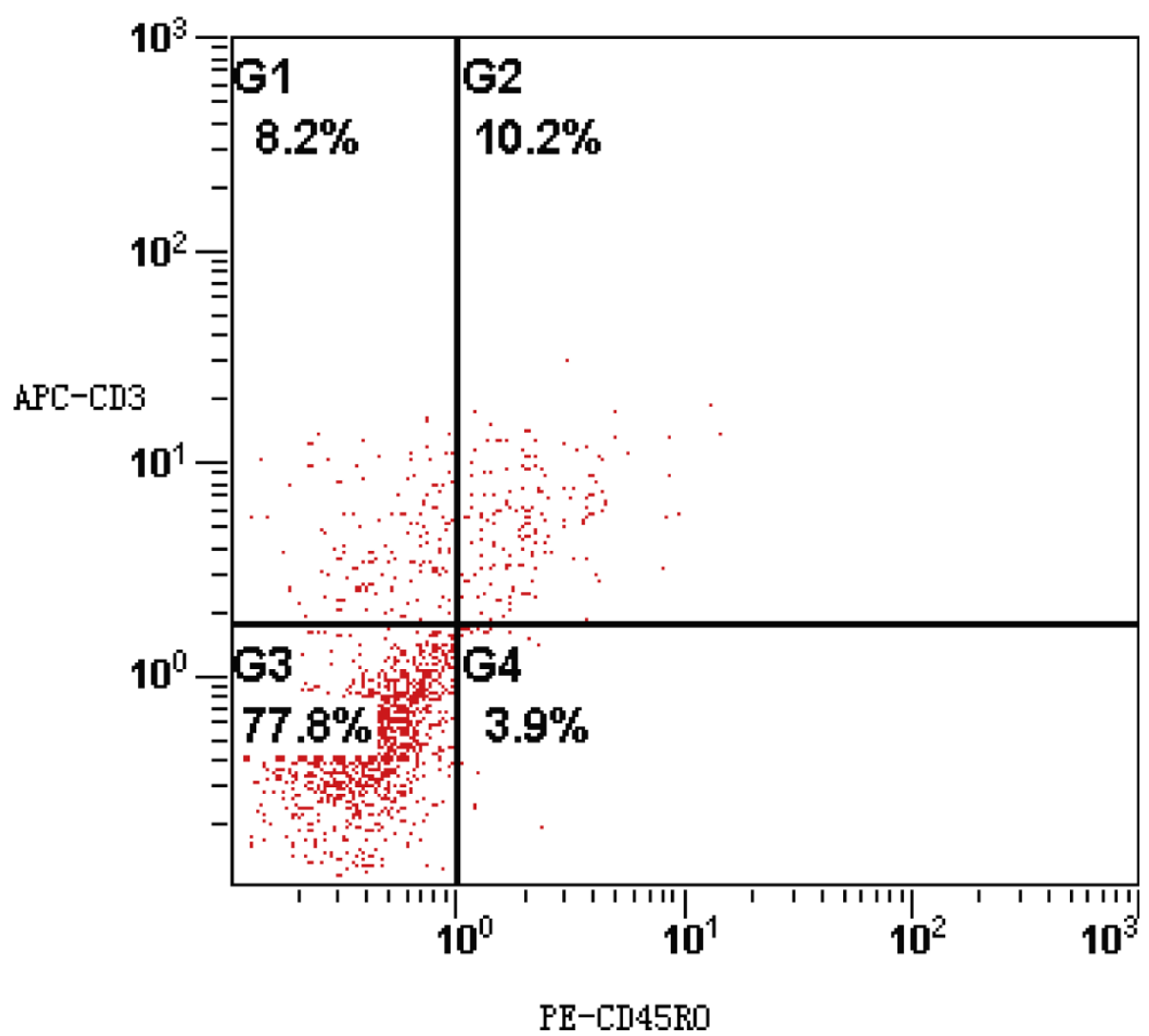

Figure 3 Co-expression of CD3 and CD45RO antigens among TILs analyzed with flow cytometry.

indicated that a higher density of either CD3+ or CD45RO+ cells within the tumor was associated with a higher 5-year survival rate (Fig. 6). However, the association between the patterns of HMGB1 expression and 5 -year survival rate was complicated. The survival curves crossed at 24 months between patients with nuclearonly expression of HMGB1 and those with co-expression of nuclear and cytoplasmic HMGB1 (Fig.7A). Kaplan-Meier survival analysis revealed no statistical difference in survival between the patients with nuclearonly expression of HMGB1 and those with co-expression of nuclear and cytoplasmic HMGB1 within 24 months after surgery. After 24 months, the patients with the co-expression of nuclear and cytoplasmic HMGB1 showed a lower 5-year survival rate compared

Table 2 Patterns of HMGB1 expression in stage IIIB colon cancers $(\mathbf{N}=\mathbf{7 2})$

\begin{tabular}{ccccc}
\hline & \multicolumn{4}{c}{ HMGB1 expression } \\
$\mathbf{0}$ & \multicolumn{4}{c}{$+\mathbf{+ + - + +}$} \\
\cline { 2 - 5 } & nuclear & nuclear and & nuclear & nuclear only nuclear and \\
& only & cytoplasmic & only & cytoplasmic \\
7 & 20 & 5 & 33 & 7 \\
\hline
\end{tabular}

with the patients with nuclear-only expression of HMGB1 (Table 5, Fig. 7B).

Relationship between the density of TILs, the level or subcellular location of HMGB1, clinical characteristics, and 5-year survival rate as analyzed via multivariate survival analysis

The Cox regression model revealed that only those patients with a higher density of CD45RO+ cells within the tumor stroma had a longer survival, whereas no relationship was observed between the survival and the density of CD3+ cells. There was also no relationship between the survival and the levels or the subcellular distribution (nucleus only or nucleus combined with cytoplasm) of HMGB1 in primary tumors. These results indicated that in this group of patients, the density of CD45RO+ cells within the tumor was independently prognostic (Table 6). The same result occurred in the time-dependent multivariate survival analysis (data not shown).

\section{Discussion}

To determine the role of HMGB1 in the progression of colon cancer, this study examined the patterns of 


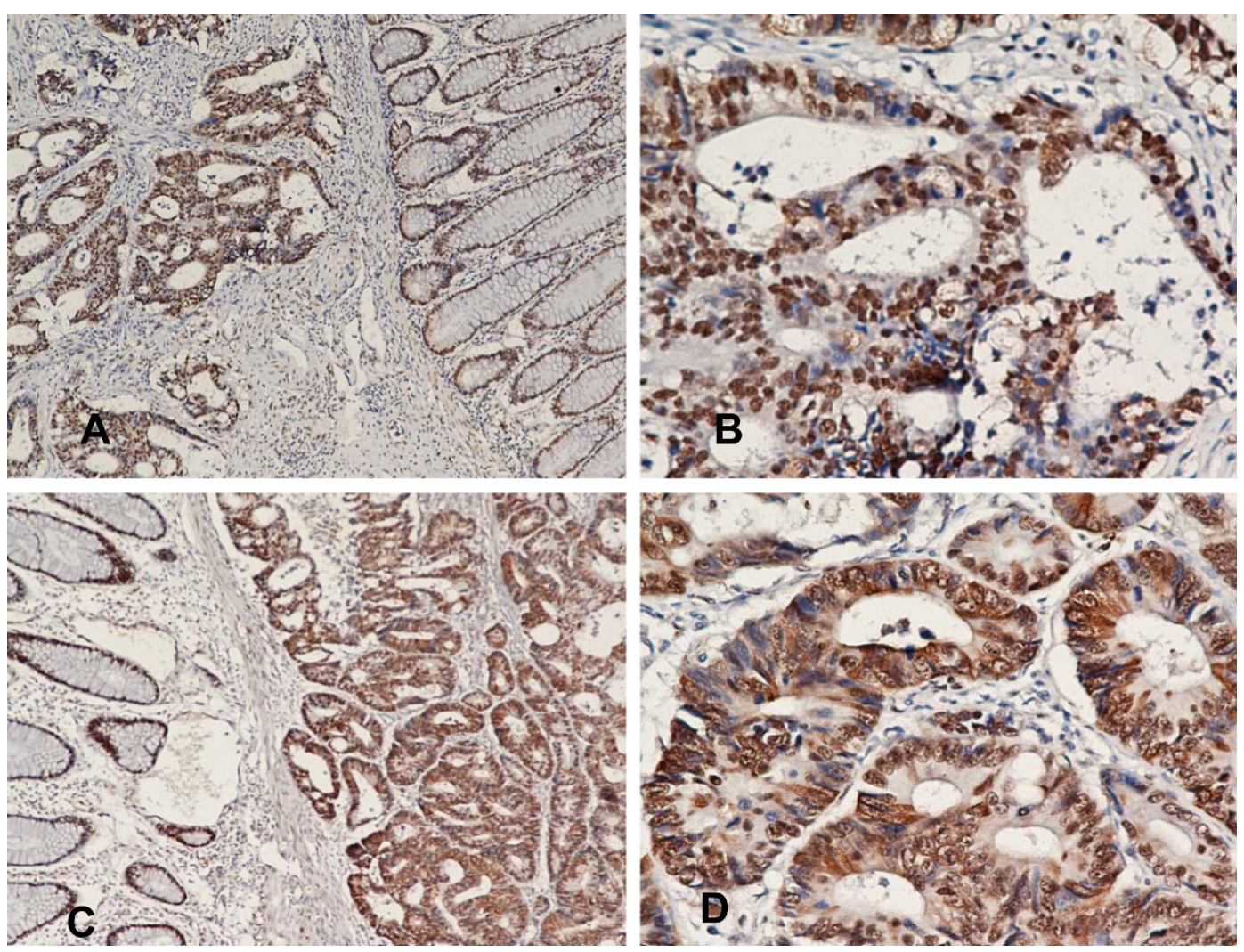

Figure 4 Expression of HMGB1 in colon cancer and the adjacent normal mucosa. Nuclear staining of HMGB1 ( $\times 100$ in $A$ and $\times 400$ in $B)$ and nuclear and cytoplasmic staining of HMGB1 ( $\times 100$ in C and $\times 400$ in D).

Table 3 Relationship between the expression of HMGB1 and the density of TILs as well as patient characteristics $(\mathrm{N}=\mathbf{7 2})$

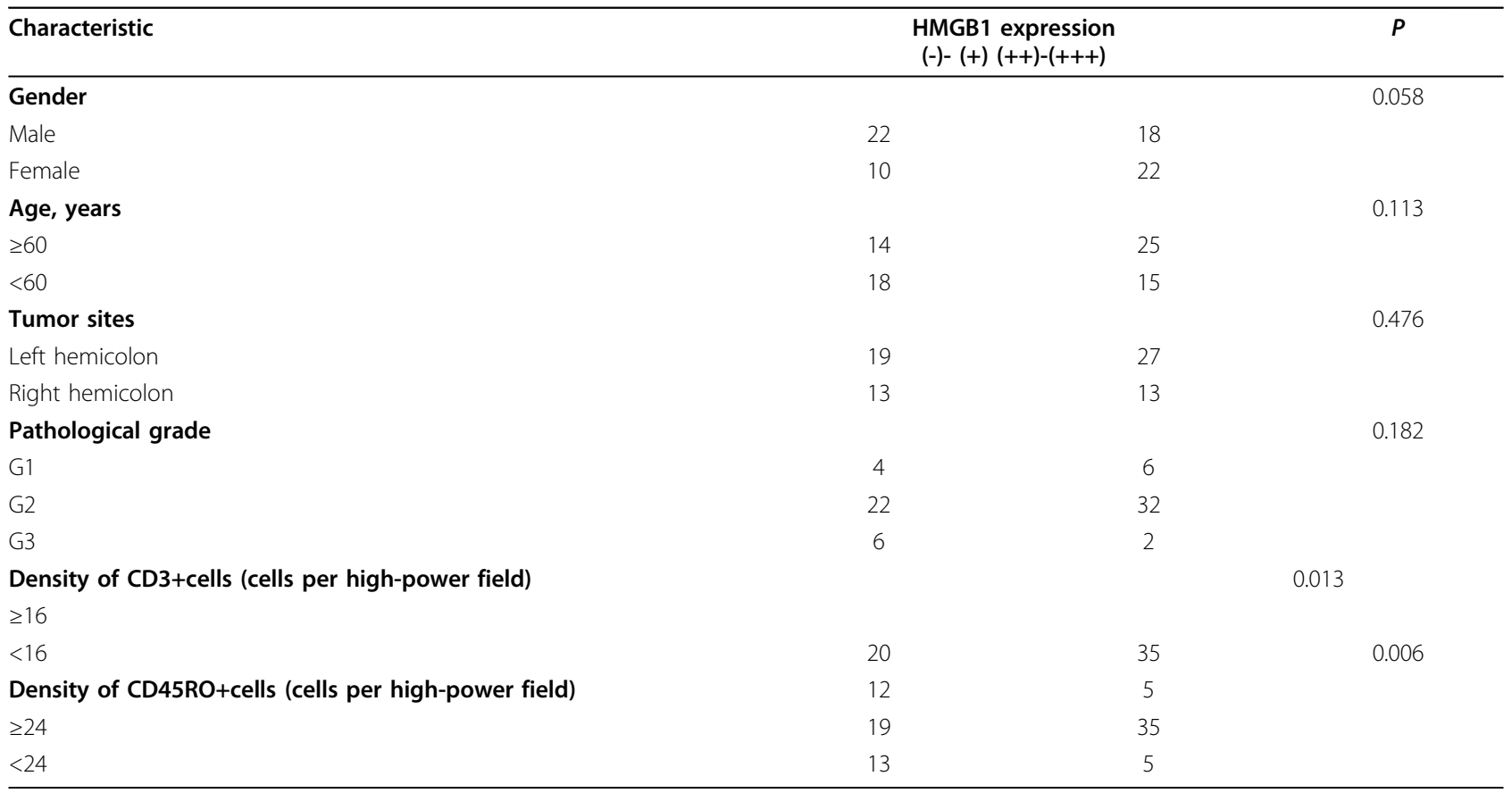




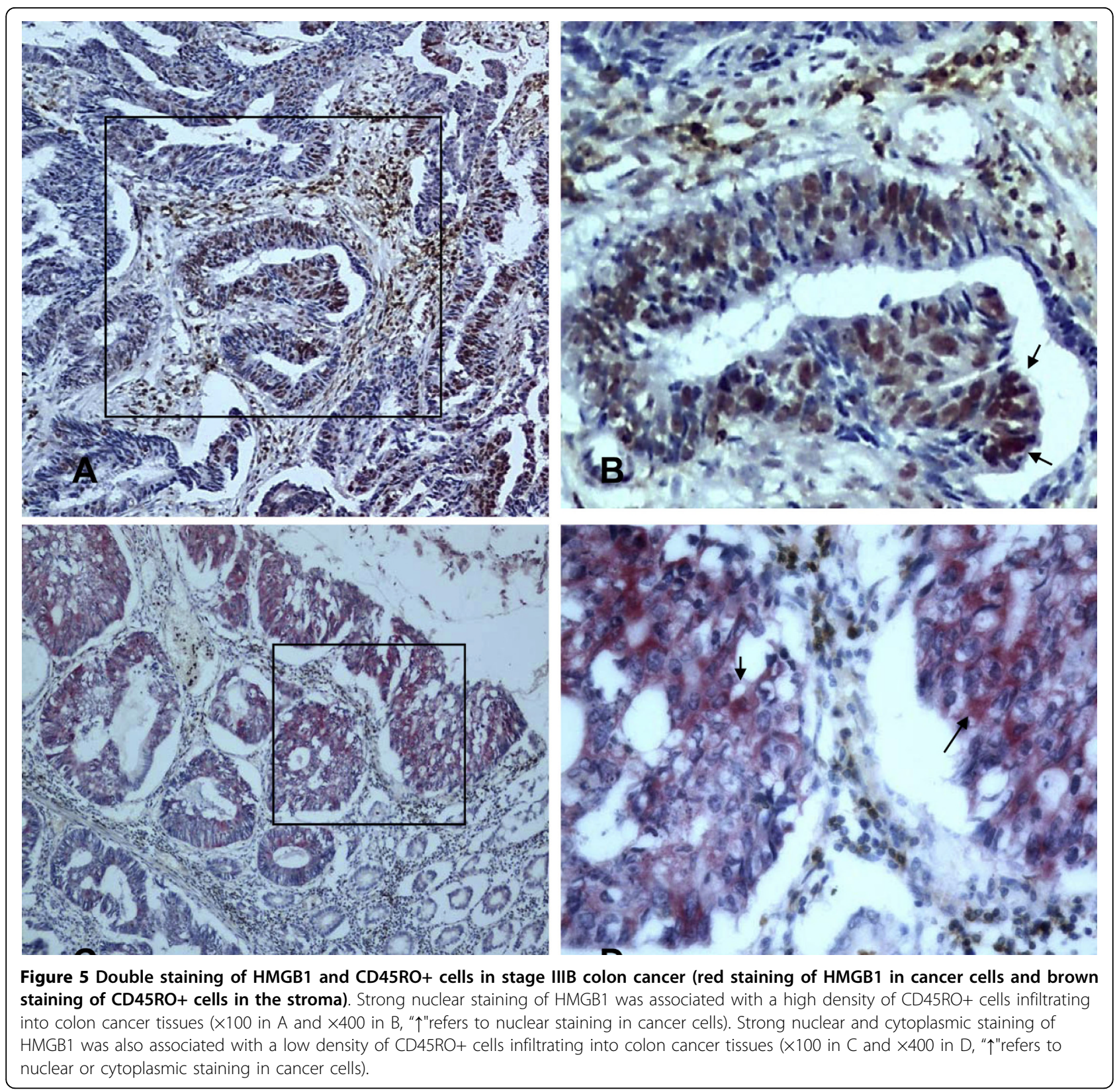

Table 4 Relationship between subcellular localization of HMGB1 and density of TILs ( $N=65)$

\begin{tabular}{|c|c|c|c|}
\hline \multicolumn{3}{|c|}{ Subcellular localization of HMGB1 } & \multirow[t]{2}{*}{$P$ value } \\
\hline & nuclear only & nuclear and cytoplasmic & \\
\hline \multicolumn{4}{|c|}{ Density of CD3+cells (cells per high-power field) } \\
\hline$\geq 16$ & 47 & 5 & 0.000 \\
\hline$<16$ & 6 & 7 & \\
\hline \multicolumn{4}{|c|}{ Density of CD45RO+cells (cells per high-power field) } \\
\hline$\geq 24$ & 46 & 5 & 0.0001 \\
\hline$<24$ & 7 & 7 & \\
\hline
\end{tabular}




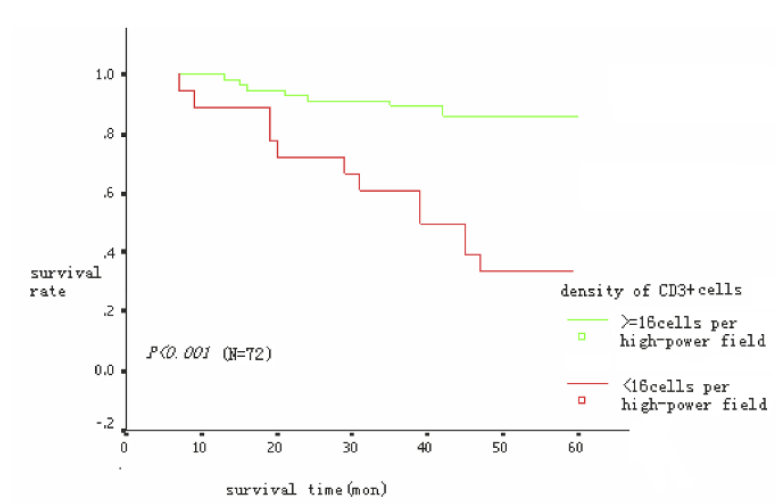

A

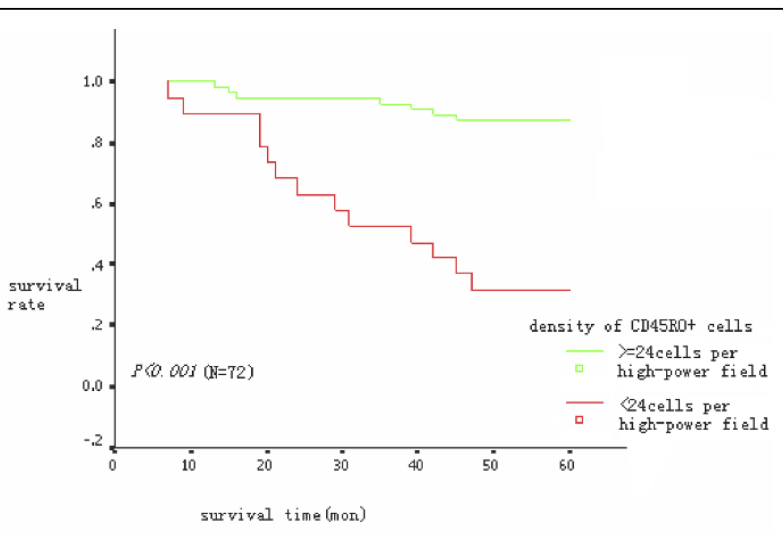

B

Figure 6 The association between overall survival with the density of CD3+ and CD45RO+ cells as well as HMGB1 expression in stage IIIB colon cancers. A high density of CD3+ cells within the tumor was associated with a longer 5-year survival rate (A); a high density of CD45RO+cells within the tumor was associated with a longer 5-year survival rate (B).

HMGB1 expression and their relationship with the infiltration of $\mathrm{T}$ cells and the 5-year survival rate in patients with stage IIIB colon cancer. The results showed that the density of CD45RO+ T cells within the cancer tissue was independently prognostic. More importantly, the co-expression pattern of nuclear and cytoplasmic HMGB1 in cancer cells was inversely related to the infiltration of $\mathrm{CD} 3+$ or $\mathrm{CD} 45 \mathrm{RO}+\mathrm{T}$ cells and patient 5-year survival rate. These data indicate that the pattern of HMGB1 expression is related to the progression of colon cancer.

The role of TILs in colorectal cancer has been discussed extensively during the past 3 decades, but controversy continues. Recently, two studies have focused on the role of memory $\mathrm{T}$ cells in the progression of colorectal cancer. Pagès et al. [16] concentrated on the role of TILs in the early metastatic invasion of 959 cases of colorectal cancer and observed increasing levels of TILs, especially CD45RO+ memory cells, in tumors without pathologic signs of early metastatic invasion. The increasing levels of TILs were correlated with a less advanced pathologic stage and increased survival, indicating the potential of $\mathrm{CD} 45 \mathrm{RO}+$ memory cells for

Table 5 Relationship between the localization of HMGB1 and prognosis after 24 months of follow-up ( $N=57)$

\begin{tabular}{|c|c|c|c|}
\hline & \multicolumn{2}{|c|}{ Subcellular location of HMGB1 } & \multirow{2}{*}{$\begin{array}{c}P \\
\text { value }\end{array}$} \\
\hline & $\begin{array}{c}\text { nuclear } \\
\text { only }\end{array}$ & $\begin{array}{l}\text { nuclear and } \\
\text { cytoplasmic }\end{array}$ & \\
\hline $\begin{array}{l}\text { Survival time } \\
\text { (months) }\end{array}$ & & & $<0.001$ \\
\hline$\geq 60$ & 43 & 5 & \\
\hline$\geq 24 a$ and $<60$ & 3 & 6 & \\
\hline
\end{tabular}

limiting early metastasis of colorectal cancer. Galon et al. [17] explored the role of the adaptive immune response in controlling growth and recurrence in 454 cases of human colorectal cancer and found that patients with a higher density of CD3+ and CD45RO+ cells in the tumor center and the invasive margins of the tumor samples had prolonged disease-free survival, indicating that the type, density, and location of immune cells within the tumor samples were predictors of survival. Both of these studies revealed the protective role of $\mathrm{CD} 45 \mathrm{RO}+$ memory cells in early colorectal cancer. The present study revealed that the infiltration of $\mathrm{CD} 45 \mathrm{RO}+$ cells was also protective in locally advanced colon cancer. As $72 \%$ of CD45RO+ cells were also positive for $\mathrm{CD} 3$, the protective CD45RO + cells in colon cancer should be predominantly CD3+CD45RO+ memory $\mathrm{T}$ cells. Although a higher density of CD3+ T cells was also associated with a favorable prognosis in univariate analysis, this prognostic value was not apparent in multivariate analysis, an observation that is also consistent with a recent study [39].

Since the memory $\mathrm{T}$ cells residing in colon cancers result from an acute immunologic response, this study further examined whether HMGB1 was involved in this process. A higher level of HMGB1 was associated with a poorer prognosis or more malignant phenotypes in multiple solid tumors, such as nasopharyngeal, lung, skin, hepatic, gastric, and prostate cancers, with the exception of breast cancer [40-46]. Previous studies have shown that the co-expression of RAGE and HMGB1 led to enhanced migration and invasion by colon cancer cell lines. Furthermore, increased RAGE expression in colon cancers has been associated with atypia, adenoma size, and metastasis to other organs. Additionally, stage I 


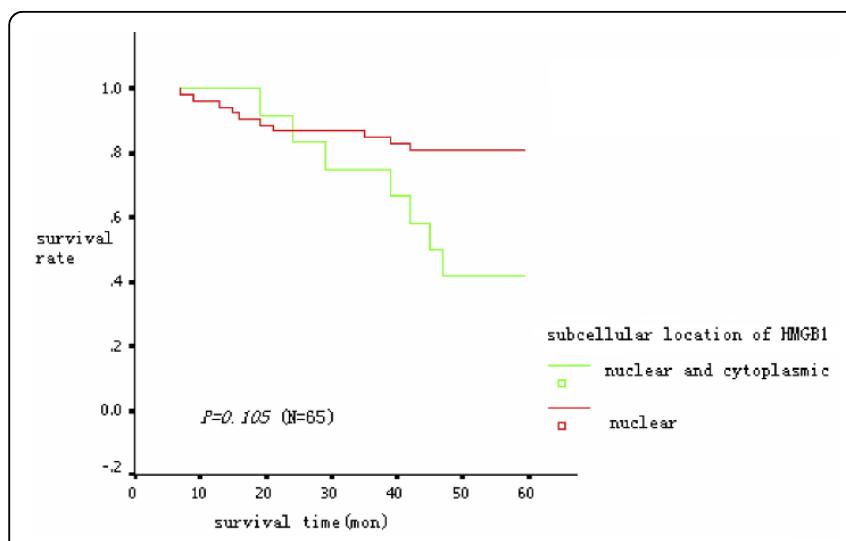

A

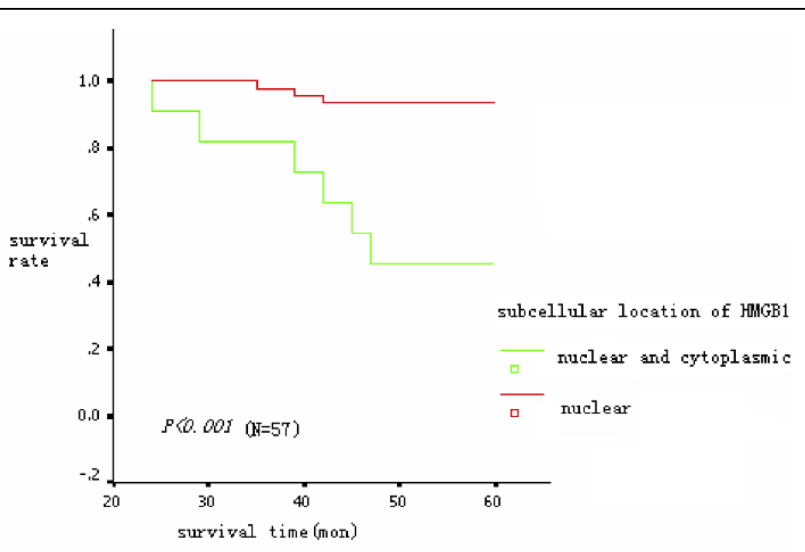

B

Figure 7 The association between overall survival and the subcellular localization of HMGB1 in stage IIIB colon cancers. No significant correlation with 5-year survival for patients with nuclear or nuclear and cytoplasmic expression of HMGB1 in cancer cells was observed because the survival curves crossed at 24 months (A), nuclear and cytoplasmic expression of HMGB1 in cancer cells was inversely associated with prognosis after 24 months of follow-up (B).

tumors have relatively lower expression levels of HMGB1, whereas stage IV tumors have near-universal expression of HMGB1 [47-52]. However, only a few studies have shown the association between HMGB1 expression and 5-year survival in colon cancer patients. Recent clinical evidence showed that the overexpression of HMGB1 in colorectal cancer was related to malignant phenotypes and shorter survival times [53-55]. To decrease the bias from factors like TNM stage and rectal cancers, this study analyzed specimens only from stage IIIB colon cancer patients. The results indicated that the co-expression of nuclear and cytoplasmic HMGB1 in colon cancer cells was associated with a poor prognosis. In normal colon mucosa, the expression of HMGB1 was observed only in the nucleus. In colon cancer cells, the co-expression pattern of HMGB1 in the nucleus and cytoplasm was observed in a subset of cancer cells, whereas nuclear-only expression of HMGB1 existed in most colon cancer cells. The survival curves of patients with the nuclear-only expression pattern and those with a pattern of co-expression crossed at 24 months after surgery, a result that might derive from the relatively small number of cases in this study, as no statistically significant difference was detected. However, KaplanMeier survival analysis showed that the patients with the pattern of co-expression of HMGB1 had a lower 5-year survival rate after 24 months of follow-up than those patients with HMGB1 expression in the nucleus only. This effect suggested that the pattern of co-expression of HMGB1 in cancer cells interfered with the long-term survival by partially modulating the immune response in a subset of colon cancer patients.

Because HMGB1 is a DAMP, the association between the expression of HMGB1 and the infiltration of TILs was further analyzed in this study. The results showed that co-expression of nuclear and cytoplasmic HMGB1 was also inversely related to the infiltration of CD45RO + cells and CD3+ cells, again arguing that the effect of the pattern of co-expression of HMGB1 on survival was associated with the local modulation of the immunologic response by HMGB1. The mechanism underlying this inverse association is still elusive. One possibility is

Table 6 Multivariate survival analysis $(N=72)$

\begin{tabular}{|c|c|c|c|c|c|c|c|c|}
\hline & B & SE & Wald & df & Sig. & $\operatorname{Exp}(B)$ & $95 \% \mathrm{Cl}$ for Lower & Upper $\operatorname{Exp}(B)$ \\
\hline Pathological grade & .375 & .257 & 2.120 & 1 & .145 & 1.454 & .878 & 2.408 \\
\hline Gender & -.111 & .270 & .168 & 1 & .682 & .895 & .527 & 1.520 \\
\hline Age & .019 & .242 & .006 & 1 & .936 & 1.020 & .634 & 1.638 \\
\hline Tumor sites & .015 & .253 & .004 & 1 & .952 & 1.015 & .619 & 1.666 \\
\hline Density of CD3+ cells & -.569 & .351 & 2.632 & 1 & .105 & .566 & .285 & 1.126 \\
\hline Density of CD45RO+ cells & -.883 & .376 & 5.524 & 1 & .019 & .414 & .198 & .864 \\
\hline Level of HMGB1 & .099 & .300 & .110 & 1 & .740 & 1.105 & .613 & 1.989 \\
\hline Localization of HMGB1 & -.130 & .229 & .322 & 1 & .570 & .878 & .560 & 1.376 \\
\hline
\end{tabular}


that HMGB1 secreted by colon cancers promotes the angiogenesis switch and increases cancer cell invasiveness [56-59]. Another potential mechanism is that extracellular HMGB1 triggers the inflammatory cascade, modulates the local immunologic microenvironment towards tolerance by polarizing the response of helper $\mathrm{T}$ cells and improperly activating macrophages and DCs [60-64]. There is evidence suggesting that both aforementioned mechanisms might contribute to the progression of colon cancer. For example, in colon cancer cell lines, E-selectin downregulated the cellular expression of HMGB1 but enhanced the release of HMGB1 into the culture medium. The released HMGB1, in turn, activated endothelial cells to express E-selectin [65]. Additionally, the higher level of HMGB1 detected in DCs existed in the metastatic lymph nodes of colon cancer patients [66]. Therefore, HMGB1-releasing colon cancer cells might promote effective angiogenesis and immune escape.

Several lines of evidence indicate that chemotherapy or radiation therapy induce the release of HMGB1 from dying cells, and this damage-related, acute release of HMGB1 is involved in the protective immune response [67-69]. This study observed that the co-expression of HMGB1 in the nuclear and cytoplasm was associated with poorer prognoses and lower infiltration of $\mathrm{CD} 45 \mathrm{RO}+$ cells, suggesting that spontaneous release and damage-induced release of HMGB1 might act differently in the progression of colon cancer. However, This study was just a descriptive one, more functional work should be done to reveal the mechanisms underlying this process. Therefore, different strategies should be considered when targeting HMGB1 under the conditions of spontaneous chronic release and damage-related, acute release of HMGB1 [70-72].

\section{Conclusion}

This study observed that the co-expression of nuclear and cytoplasmic HMGB1 was inversely associated with the infiltration of CD45RO+ cells and the 5-year survival rate in patients with stage IIIB colon cancer. These observations indicated that the distribution patterns of HMGB1 contribute to the progression of colon cancer. The co-expression of nuclear and cytoplasmic HMGB1 might be used as a marker for poor survival in patients with local advanced colon cancer.

\section{Acknowledgements}

This study was supported by the National Nature Science Foundation (30872931) and the National Nature Science Foundation, China (30972882).

\footnotetext{
Author details

'State Key Laboratory of Oncology in South China, 651 Dongfeng R E, 510060, Guangzhou, China. Biotherapy Center, Cancer Center, Sun Yat-sen University, 651 Dongfeng R E, 510060, Guangzhou, China. ${ }^{3}$ Department of
}

Colorectal Surgery, Cancer Center, Sun Yat-sen University, 651 Dongfeng R E, 510060, Guangzhou, China. ${ }^{4}$ Department of Experimental Research, Cancer Center, Sun Yat-sen University, 651 Dongfeng R E, 510060, Guangzhou, China. ${ }^{5}$ Biotherapy Center, The First Affiliated Hospital, Chongqing Medical University, 1 Youyi R, 400016, Chongqing, China.

\section{Authors' contributions}

WXJ, DY, ZX, PZZ, WDS, and ZLM carried out the case collection. PRQ, LCY, and $Y X J$ carried out the immunohistochemical staining and flow cytometry analyses. ZXS and ZYX conceived the study, participated in its design and coordination, and helped draft the manuscript. All authors read and approved the final manuscript.

\section{Competing interests}

The authors declare that they have no competing interests.

Received: 3 September 2009 Accepted: 16 September 2010 Published: 16 September 2010

\section{References}

1. Jemal A, Siegel R, Ward E, Hao Y, Xu J, Murray T, Thun MJ: Cancer statistics, 2008. CA Cancer J Clin 2008, 58:71-96.

2. Meyerhardt JA, Mayer RJ: Systemic therapy for colorectal cancer. N Engl J Med 2005, 352:476-487.

3. Fletcher RH: The diagnosis of colorectal cancer in patients with symptoms: finding a needle in a haystack. BMC Med 2009, 7:18.

4. Bathe OF, Ernst S, Sutherland FR, Dixon E, Butts C, Bigam D, Holland D, Porter GA, Koppel J, Dowden S: A phase II experience with neoadjuvant irinotecan (CPT-11), 5-fluorouracil (5-FU) and leucovorin (LV) for colorectal liver metastases. BMC Cancer 2009, 9:156.

5. Balko JM, Black EP: A gene expression predictor of response to EGFRtargeted therapy stratifies progression-free survival to cetuximab in KRAS wild-type metastatic colorectal cancer. BMC Cancer 2009, 9:145.

6. Ohtani H: Focus on TILs: prognostic significance of tumor infiltrating lymphocytes in human colorectal cancer. Cancer Immun 2007, 7:4.

7. Atreya I, Neurath MF: Immune cells in colorectal cancer: prognostic relevance and therapeutic strategies. Expert Rev Anticancer Ther 2008, 8:561-572.

8. Pagès $F$, Galon J, Fridman WH: The essential role of the in situ immune reaction in human colorectal cancer. J Leukoc Biol 2008, 84:981-987.

9. Galon J, Fridman WH, Pagès F: The adaptive immunologic microenvironment in colorectal cancer: a novel perspective. Cancer Res 2007, 67:1883-1886.

10. Camus $M$, Tosolini $M$, Mlecnik $B$, Pagès $F$, Kirilovsky $A$, Berger $A$, Costes $A$, Bindea G, Charoentong P, Bruneval P, Trajanoski Z, Fridman WH, Galon J: Coordination of intratumoral immune reaction and human colorectal cancer recurrence. Cancer Res 2009, 69:2685-2693.

11. Zlobec I, Terracciano LM, Lugli A: Local recurrence in mismatch repairproficient colon cancer predicted by an infiltrative tumor border and lack of CD8+ tumor-infiltrating lymphocytes. Clin Cancer Res 2008, 14:3792-3797.

12. Wagner P, Koch M, Nummer D, Palm S, Galindo L, Autenrieth D, Rahbari N, Schmitz-Winnenthal FH, Schirrmacher V, Büchler MW, Beckhove P, Weitz J: Detection and functional analysis of tumor infiltrating T-lymphocytes (TIL) in liver metastases from colorectal cancer. Ann Surg Oncol 2008, 15:2310-2317.

13. Nagorsen D, Voigt S, Berg E, Stein H, Thiel E, Loddenkemper C: Tumorinfiltrating macrophages and dendritic cells in human colorectal cancer: relation to local regulatory $\mathrm{T}$ cells, systemic T-cell response against tumor-associated antigens and survival. J Transl Med 2007, 5:62.

14. Halama N, Michel S, Kloor M, Zoernig I, Pommerencke T, von Knebel Doeberitz M, Schirmacher P, Weitz J, Grabe N, Jäger D: The localization and density of immune cells in primary tumors of human metastatic colorectal cancer shows an association with response to chemotherapy. Cancer Immun 2009, 9:1.

15. Morris $M$, Platell $C$, lacopetta B: Tumor-infiltrating lymphocytes and perforation in colon cancer predict positive response to 5 -fluorouracil chemotherapy. Clin Cancer Res 2008, 14:1413-1417.

16. Pagès F, Berger $A$, Camus $M$, Sanch ez-Cabo F, Costes A, Molidor R, Mlecnik B, Kirilovsky A, Nilsson M, Damotte D, Meatchi T, Bruneval P, Cugnenc PH, Trajanoski Z, Fridman WH, Galon J: Effector memory T cells, 
early metastasis, and survival in colorectal cancer. N Engl J Med 2005, 353:2654-2666

17. Galon J, Costes A, Sanchez-Cabo F, Kirilovsky A, Mlecnik B, Lagorce-Pagès C, Tosolini M, Camus M, Berger A, Wind P, Zinzindohoué F, Bruneval P, Cugnenc PH, Trajanoski Z, Fridman WH, Pagès F: Type, density, and location of immune cells within human colorectal tumors predict clinical outcome. Science 2006, 313:1960-1964.

18. Masopust $D$, Vezys V, Marzo AL, Lefrançois L: Preferential localization of effector memory cells in nonlymphoid tissue. Science 2001, 291:2413-2417.

19. Vezys V, Yates A, Casey KA, Lanier G, Ahmed R, Antia R, Masopust D: Memory CD8 T-cell compartment grows in size with immunological experience. Nature 2009, 457:196-199.

20. Clémenceau B, Vivien R, Berthomé M, Robillard N, Garand R, Gallot G, Vollant S, Vié H: Effector memory alphabeta T lymphocytes can express FcgammaRIIlla and mediate antibody-dependent cellular cytotoxicity. J Immunol 2008, 180:5327-5334.

21. Woodland DL, Kohlmeier JE: Migration, maintenance and recall of memory T cells in peripheral tissues. Nat Rev Immunol 2009, 9:153-161

22. Correale P, Cusi MG, Tsang KY, Del Vecchio MT, Marsili S, Placa ML, Intrivici C, Aquino A, Micheli L, Nencini C, Ferrari F, Giorgi G, Bonmassar E, Francini G: Chemo-immunotherapy of metastatic colorectal carcinoma with gemcitabine plus FOLFOX 4 followed by subcutaneous granulocyte macrophage colony-stimulating factor and interleukin-2 induces strong immunologic and antitumor activity in metastatic colon cancer patients. J Clin Oncol 2005, 23:8950-8958.

23. Correale P, Tagliaferri P, Fioravanti A, Del Vecchio MT, Remondo C, Montagnani F, Rotundo MS, Ginanneschi C, Martellucci I, Francini E, Cusi MG, Tassone P, Francini G: Immunity feedback and clinical outcome in colon cancer patients undergoing chemoimmunotherapy with gemcitabine + FOLFOX followed by subcutaneous granulocyte macrophage colony-stimulating factor and aldesleukin (GOLFIG-1 Trial). Clin Cancer Res 2008, 14:4192-4199.

24. Green DR, Ferguson T, Zitvogel L, Kroemer G: Immunogenic and tolerogenic cell death. Nat Rev Immunol 2009, 9:353-363.

25. Kepp O, Tesniere A, Schlemmer F, Michaud M, Senovilla L, Zitvogel L, Kroemer G: Immunogenic cell death modalities and their impact on cancer treatment. Apoptosis 2009, 14:364-375.

26. Kepp O, Tesniere A, Zitvogel L, Kroemer G: The immunogenicity of tumor cell death. Curr Opin Oncol 2009, 21:71-76.

27. Haynes NM, van der Most RG, Lake RA, Smyth MJ: Immunogenic anticancer chemotherapy as an emerging concept. Curr Opin Immunol 2008, 20:545-557.

28. Campana L, Bosurgi L, Rovere-Querini P: HMGB1: a two-headed signal regulating tumor progression and immunity. Curr Opin Immunol 2008, 20:518-523.

29. Tesniere A, Apetoh L, Ghiringhelli F, Joza N, Panaretakis T, Kepp O, Schlemmer F, Zitvogel L, Kroemer G: Immunogenic cancer cell death: a key-lock paradigm. Curr Opin Immunol 2008, 20:504-511.

30. Yang J, Shah R, Robling AG, Templeton E, Yang H, Tracey KJ, Bidwell JP: HMGB1 is a bone-active cytokine. J Cell Physiol 2008, 214:730-739.

31. Klune JR, Dhupar R, Cardinal J, Billiar TR, Tsung A: HMGB1: endogenous danger signaling. Mol Med 2008, 14:476-484.

32. Kusume A, Sasahira T, Luo Y, Isobe M, Nakagawa N, Tatsumoto N, Fujii K, Ohmori H, Kuniyasu H: Suppression of dendritic cells by HMGB1 is associated with lymph node metastasis of human colon cancer. Pathobiology 2009, 76:155-162.

33. Kazama H, Ricci JE, Herndon JM, Hoppe G, Green DR, Ferguson TA: Induction of immunological tolerance by apoptotic cells requires caspase-dependent oxidation of high-mobility group box-1 protein. Immunity 2008, 29:21-32.

34. Popovic PJ, DeMarco R, Lotze MT, Winikoff SE, Bartlett DL, Krieg AM, Guo ZS, Brown CK, Tracey K, Zeh HJ: High mobility group B1 protein suppresses the human plasmacytoid dendritic cell response to TLR9 agonists. J Immunol 2006, 177:8701-8707.

35. Ulloa L, Messmer D: High-mobility group box 1 (HMGB1) protein: friend and foe. Cytokine Growth Factor Rev 2006, 17:189-201.

36. Apetoh L, Mignot G, Panaretakis T, Kroemer G, Zitvogel L: Immunogenicity of anthracyclines: moving towards more personalized medicine. Trends Mol Med 2008, 14:141-151.
37. Hussein MR, Hassan HI: Analysis of the mononuclear inflammatory cell infiltrate in the normal breast, benign proliferative breast disease, in situ and infiltrating ductal breast carcinomas: preliminary observations. J Clin Pathol 2006, 59:972-977.

38. Soumaoro LT, Uetake $H$, Higuchi T, Takagi Y, Enomoto M, Sugihara K: Cyclooxygenase-2 expression: a significant prognostic indicator for patients with colorectal cancer. Clin Cancer Res 2004, 10:8465-8471.

39. Laghi L, Bianchi P, Miranda E, Balladore E, Pacetti V, Grizzi F, Allavena P, Torri V, Repici A, Santoro A, Mantovani A, Roncalli M, Malesci A: CD3+ cells at the invasive margin of deeply invading (pT3-T4) colorectal cancer and risk of post-surgical metastasis: a longitudinal study. Lancet Oncol 2009, 3.

40. Wu D, Ding Y, Wang S, Zhang Q, Liu L: Increased expression of high mobility group box 1 (HMGB1) is associated with progression and poor prognosis in human nasopharyngeal carcinoma. J Pathol 2008, 216:167-175

41. Shen $X$, Hong L, Sun $H$, Shi M, Song Y: The expression of high-mobility group protein box 1 correlates with the progression of non-small cell lung cancer. Oncol Rep 2009, 22:535-539.

42. Cardinal J, Pan P, Dhupar R, Ross M, Nakao A, Lotze M, Billiar T, Geller D, Tsung A: Cisplatin prevents high mobility group box 1 release and is protective in a murine model of hepatic ischemia/reperfusion injury. Hepatology 2009, 50:565-574.

43. Sharma A, Ray R, Rajeswari MR: Overexpression of high mobility group (HMG) B1 and B2 proteins directly correlates with the progression of squamous cell carcinoma in skin. Cancer Invest 2008, 26:843-851.

44. Jiao Y, Wang HC, Fan SJ: Growth suppression and radiosensitivity increase by HMGB1 in breast cancer. Acta Pharmacol Sin 2007, 28:1957-1967.

45. Flohr AM, Rogalla P, Meiboom M, Borrmann L, Krohn M, Thode-Halle B, Bullerdiek J: Variation of HMGB1 expression in breast cancer. Anticancer Res 2001, 21:3881-3885.

46. Nagatani $G$, Nomoto $M$, Takano $H$, Ise $T$, Kato $K$, Imamura $T$, Izumi $H$, Makishima K, Kohno K: Transcriptional activation of the human HMG1 geneincisplatin-resistant human cancer cells. Cancer Res 2001, 61:1592-1597.

47. Kang HJ, Lee H, Choi HJ, Youn JH, Shin JS, Ahn YH, Yoo JS, Paik YK, Kim H: Non-histone nuclear factor HMGB1 is phosphorylated and secreted in colon cancers. Lab Invest 2009, 89:948-959.

48. Logsdon CD, Fuentes MK, Huang EH, Arumugam T: RAGE and RAGE ligands in cancer. Curr Mol Med 2007, 7:777-789.

49. Balasubramani M, Day BW, Schoen RE, Getzenberg RH: Altered expression and localization of creatine kinase $B$, heterogeneous nuclear ribonucleoprotein $\mathrm{F}$, and high mobility group box 1 protein in the nuclear matrix associated with colon cancer. Cancer Res 2006, 66:763-769.

50. Kuniyasu H, Chihara Y, Takahashi T: Co-expression of receptor for advanced glycation end products and the ligand amphoterin associates closely with metastasis of colorectal cancer. Oncol Rep 2003, 10:445-448.

51. Sasahira T, Akama Y, Fujii K, Kuniyasu H: Expression of receptor for advanced glycation end products and HMGB1/amphoterin in colorectal adenomas. Virchows Arch 2005, 446:411-415.

52. Kuniyasu $H$, Chihara $Y$, Kondo $H$ : Differential effects between amphoterin and advanced glycation end products on colon cancer cells. Int I Cancer 2003, 104:722-727.

53. Yao X, Zhao G, Yang H, Hong X, Bie L, Liu G: Overexpression of highmobility group box 1 correlates with tumor progression and poor prognosis in human colorectal carcinoma. J Cancer Res Clin Oncol 2010, 136:677-684.

54. Luo Y, Ohmori H, Fujii K, Moriwaka Y, Sasahira T, Kurihara M, Tatsumoto N, Sasaki T, Yamashita Y, Kuniyasu H: HMGB1 attenuates anti-metastatic defence of the liver in colorectal cancer. Eur J Cancer 2010, 46:791-799.

55. Moriwaka Y, Luo Y, Ohmori H, Fujii K, Tatsumoto N, Sasahira T, Kuniyasu H: HMGB1 attenuates anti-metastatic defense of the lymph nodes in colorectal cancer. Pathobiology 2010, 77:17-23.

56. Ellerman JE, Brown CK, de Vera M, Zeh HJ, Billiar T, Rubartelli A, Lotze MT: Masquerader: high mobility group box-1 and cancer. Clin Cancer Res 2007, 13:2836-2848.

57. Chavakis E, Hain A, Vinci M, Carmona G, Bianchi ME, Vajkoczy P, Zeiher AM, Chavakis T, Dimmeler S: High-mobility group box 1activates integrindependent homing of endothelial progenitor cells. Circ Res 2007, 100:204-212. 
58. Schlueter C, Weber H, Meyer B, Rogalla P, Roser K, Hauke S, Bullerdiek J: Angiogenetic signaling through hypoxia: HMGB1: an angiogenetic switch molecule. Am J Pathol 2005, 166:1259-1263.

59. Mitola S, Belleri M, Urbinati C, Coltrini D, Sparatore B, Pedrazzi M, Melloni E, Presta M: Cutting edge: extracellular high mobility group box-1 protein is a proangiogenic cytokine. J Immunol 2006, 176:12-15.

60. Sha Y, Zmijewski J, Xu Z, Abraham E: HMGB1 develops enhanced proinflammatory activity by binding to cytokines. J Immunol 2008, 180:2531-2537.

61. Lotze MT, Zeh HJ, Rubartelli A, Sparvero L, Amoscato AA, Washburn NR, Devera ME, Liang $X$, Tör M, Billiar T: The grateful dead: damage-associated molecular pattern molecules and reduction/oxidation regulate immunity. Immunol Rev 2007, 220:60-81.

62. Kuniyasu H, Sasaki T, Sasahira T, Ohmori H, Takahashi T: Depletion of tumor-infiltrating macrophages is associated with amphoterin expression in colon cancer. Pathobiology 2004, 71:129-136.

63. Srikrishna G, Freeze HH: Endogenous damage-associated molecular pattern molecules at the crossroads of inflammation and cancer. Neoplasia 2009, 11:615-628.

64. Sun NK, Chao CC: The cytokine activity of HMGB1-extracellular escape of the nuclear protein. Chang Gung Med J 2005, 28:673-682.

65. Aychek T, Miller K, Sagi-Assif O, Levy-Nissenbaum O, Israeli-Amit M, Pasmanik-Chor M, Jacob-Hirsch J, Amariglio N, Rechavi G, Witz IP: E-selectin regulates gene expression in metastatic colorectal carcinoma cells and enhances HMGB1 release. Int I Cancer 2008, 123:1741-1750.

66. Kusume A, Sasahira T, Luo Y, Isobe M, Nakagawa N, Tatsumoto N, Fujii K, Ohmori H, Kuniyasu H: Suppression of dendritic cells by HMGB1 is associated with lymph node metastasis of human colon cancer. Pathobiology 2009, 76:155-162.

67. Apetoh L, Ghiringhelli F, Tesniere A, Obeid M, Ortiz C, Criollo A, Mignot G, Maiuri MC, Ullrich E, Saulnier P, Yang H, Amigorena S, Ryffel B, Barrat FJ, Saftig P, Levi F, Lidereau R, Nogues C, Mira JP, Chompret A, Joulin V, ClavelChapelon F, Bourhis J, André F, Delaloge S, Tursz T, Kroemer G, Zitvogel L: Toll-like receptor 4-dependent contribution of the immune system to anticancer chemotherapy and radiotherapy. Nat Med 2007, 13:1050-1059.

68. Apetoh L, Mignot G, Panaretakis T, Kroemer G, Zitvogel L: Immunogenicity of anthracyclines: moving towards more personalized medicine. Trends Mol Med 2008, 14:141-151.

69. Apetoh L, Ghiringhelli F, Tesniere A, Criollo A, Ortiz C, Lidereau R, Mariette C, Chaput N, Mira JP, Delaloge S, André F, Tursz T, Kroemer G, Zitvogel L: The interaction between HMGB1 and TLR4 dictates the outcome of anticancer chemotherapy and radiotherapy. Immunol Rev 2007, 220:47-59.

70. Dong Xda E, Ito N, Lotze MT, Demarco RA, Popovic P, Shand SH, Watkins S, Winikoff S, Brown CK, Bartlett DL, Zeh HJ: High mobility group box I (HMGB1) release from tumor cells after treatment: implications for development of targeted chemoimmunotherapy. I Immunother 2007, 30:596-606.

71. Mantell LL, Parrish WR, Ulloa L: Hmgb-1as a therapeutic target for infectious and inflammatory disorders. Shock 2006, 25:4-11.

72. Li G, Liu W, Frenz D: Cisplatin ototoxicity to the rat inner ear: a role for HMG1 and iNOS. Neurotoxicology 2006, 27:22-30.

\section{Pre-publication history}

The pre-publication history for this paper can be accessed here: http://www.biomedcentral.com/1471-2407/10/496/prepub

doi:10.1186/1471-2407-10-496

Cite this article as: Peng et al: Co-expression of nuclear and cytoplasmic HMGB1 is inversely associated with infiltration of CD45RO+ T cells and prognosis in patients with stage IIIB colon cancer. BMC Cancer 2010 10:496.

\section{Submit your next manuscript to BioMed Central and take full advantage of:}

- Convenient online submission

- Thorough peer review

- No space constraints or color figure charges

- Immediate publication on acceptance

- Inclusion in PubMed, CAS, Scopus and Google Scholar

- Research which is freely available for redistribution 